\title{
Correction to: Prediction of vibration responses in a reciprocating compressor interstage piping system using the modal expansion method
}

\author{
Claudio de O. Mendonça ${ }^{1}$. Ulisses A. Monteiro ${ }^{2} \cdot$ Ricardo H. R. Gutierrez ${ }^{2} \cdot$ Luiz A. Vaz $^{2}$. Jorivaldo Medeiros ${ }^{1}$. \\ Ediberto B. Tinoco ${ }^{1}$
}

Published online: 7 February 2022

(c) Springer-Verlag London Ltd., part of Springer Nature 2022

\section{Correction to: The International Journal of Advanced Manufacturing Technology https://doi.org/10.1007/s00170-021-08490-5}

The original article contained a mistake.

Author name "Claudio de O. Mendonsa" should be presented as "Claudio de O. Mendonça" as is now correctly shown above.

The original article has been corrected.

Publisher's Note Springer Nature remains neutral with regard to jurisdictional claims in published maps and institutional affiliations.

The original article can be found online at https://doi.org/10.1007/ s00170-021-08490-5.

Claudio de O. Mendonça

claudiomendonca@ petrobras.com.br

Ulisses A. Monteiro

ulisses@oceanica.ufrj.br

Ricardo H. R. Gutierrez

rhramirez@oceanica.ufrj.br

Luiz A. Vaz

vaz@oceanica.ufrj.br

Jorivaldo Medeiros

jorivaldo@petrobras.com.br

Ediberto B. Tinoco

ediberto@petrobras.com.br

1 Basic Engineering, Petrobras Av. Henrique Valadares, 28 -

Centro, Rio de Janeiro/RJ 20231-030, Brasil

2 Laboratory of Dynamic Tests and Vibration Analysis (LEDAV), Ocean Engineering Program (PENO), Federal University of Rio de Janeiro (UFRJ), Av. Athos da Silveira Ramos - 149, Rio de Janeiro/RJ 21941-909, Brasil 